\title{
Industrial Waste-Derived Nanoparticles and Microspheres Can Be Potent Antimicrobial and Functional Ingredients
}

\author{
Manashi Das Purkayastha, ${ }^{1}$ Ajay Kumar Manhar, ${ }^{2}$ \\ Manabendra Mandal, ${ }^{2}$ and Charu Lata Mahanta ${ }^{1}$ \\ ${ }^{1}$ Department of Food Engineering and Technology, School of Engineering, Tezpur University, Assam 784028, India \\ ${ }^{2}$ Department of Molecular Biology and Biotechnology, School of Science, Tezpur University, Assam 784028, India \\ Correspondence should be addressed to Charu Lata Mahanta; charu@tezu.ernet.in
}

Received 30 May 2014; Accepted 17 July 2014; Published 17 September 2014

Academic Editor: Guang-Fu Yang

Copyright (C) 2014 Manashi Das Purkayastha et al. This is an open access article distributed under the Creative Commons Attribution License, which permits unrestricted use, distribution, and reproduction in any medium, provided the original work is properly cited.

\begin{abstract}
Rapeseed oilcake or press-cake is generated as bulk waste during oil extraction from oilseeds. Owing to its high protein content, further processing of oilcakes into vegetable protein generates large quantities of fibrous residue ("oil-and-protein" spent meal) as by-product, which currently has very limited practical utility. Here, we report hydrothermal carbonization of this industrial waste to convert it into carbon nanoparticles, bestowed with multitude of functionalities. We demonstrate that these nanoparticles can be assembled into micrometer-sized spheres when precipitated from water by acetone. These microspheres, with their added feature of hemocompatibility, can be potentially utilized as an encapsulation vehicle for the protection of thermolabile compounds (such as protein); however, the secondary and tertiary features of the protein were marginally perturbed by the encapsulation process. The synthesized carbon nanoparticle was found to be an effective biocidal agent, exhibiting bacterial cellular damage and complex formation with the bacterial plasmid (evident from ethidium bromide exclusion assay), which are critical for cell survival. The results show the ability to convert industrial biowaste into useful nanomaterials for use in food industries and also suggest new scalable and simple approaches to improve environmental sustainability in industrial processes.
\end{abstract}

\section{Introduction}

Since the early 1990s, carbon nanoparticles (CNPs) have garnered considerable interest in plethora of applications. Unfortunately, application of CNP in food and its packaging materials is still in its infancy. Several methods are currently in use to synthesize CNP in the sizes from $30 \mathrm{~nm}$ to several micrometers, such as arc plasma technique, self-assembly template approach, reduction of supercritical carbon dioxide with bimetallic lithium and potassium, pyrolysis of carbon sources, hydrothermal reaction, and chemical vapour deposition [1]. However, most of these methods either use complicated equipment or require rigorous reaction conditions or are time-consuming. Sometimes the catalysts involved in the synthesis may be occasionally encapsulated in the CNP [2], thus questioning the purity of the product. The higher cost for the production of CNP and its associated lethality limits its mass production.
Endeavor to follow the dictates of sustainable development urges the global scientific community to opt for bioresources that are conferring safe "green" credentials. Biomass from food industries has been long recognized as an obvious renewable feedstock for production of various materials. Significant amount of biomass such as proteins, celluloses, and carbohydrates are discarded as waste all over the world from a variety of industries or human activities. In this milieu, oil industry generates huge quantities of oilseed press-cake as primary waste, during oil extraction. Recently, owing to the high nutritive value of the meal protein, techniques are now being devised to harness it. After the extraction of meal protein, the residual fibrous waste material ("oil-and-protein" spent meal) is discarded and is not extensively used in industries. At present there are very few possibilities for the utilization of this waste; usually the residue is disposed as landfills and, hence, is as an "end-of-pipe" waste. As industries are more and more 
forced to find an alternative use for the residual wastes, upgrading of this "end-of-pipe" waste to create a secondary use seems prudent from both economical and ecological point of view. Herein we report the facile synthesis of CNP from "oil-and-protein" spent rapeseed meal by hydrothermal carbonization (HTC). The current target remains on scrutinizing the properties of the optimally synthesized CNP and probing into its potential applications for possible use in food industries (the details of optimization using Response Surface Methodology is given in Supplementary section available online at http://dx.doi.org/10.1155/2014/171427).

\section{Experimental}

2.1. Sample Preparation and Chemicals. Rapeseed press-cake was obtained from Assam Khadi and Village Industries Board, Guwahati, India, and was detoxified prior to protein extraction according to our earlier report [3]. All solvents and reagents were obtained from E. Merck (India), of either high-performance liquid chromatography (HPLC) grade or analytical reagent grade, and were used without further purification.

\subsection{Protein Extraction from Detoxified Meal and Freeze-Thaw} Fractionation. Aqueous suspension of detoxified meal was prepared with water $(30: 1 \mathrm{v} / \mathrm{w})$, followed by the addition of $0.1 \mathrm{M} \mathrm{NaCl}$ and $0.4 \%$ sodium sulfite. The $\mathrm{pH}$ of the suspension was adjusted to $11 \pm 1$ with $1 \mathrm{~N} \mathrm{NaOH}$ solution; the suspension was mixed (200 rpm) for $1 \mathrm{~h}$ at $25^{\circ} \mathrm{C}$ in the orbital shaker (Sartorius Stedin Biotech, CERTOMAT IS), followed by centrifugation (SIGMA 3-18 K Centrifuge) at 7,000 rpm for $20 \mathrm{~min}$ at $4^{\circ} \mathrm{C}$. The solid residue (oil-and-protein-spent meal) was vacuum-dried (Lab companion model OV-12, Jeiotech Co., Korea) for $48 \mathrm{~h}$ at $40^{\circ} \mathrm{C}$, ground to pass through sieve having $250 \mu \mathrm{m}$ pores, and then stored at $-20^{\circ} \mathrm{C}$ for further use. On the other hand, the protein-rich supernatant was filtered through Whatman filter number 41 and then ammonium sulfate was added up to $85 \%$ saturation. The mixture was kept in ice bath for $3 \mathrm{~h}$ with gentle stirring and then centrifuged at $10,000 \mathrm{rpm}$ for $20 \mathrm{~min}$ at $4^{\circ} \mathrm{C}$. The obtained protein precipitate was redispersed in Milli-Q water (Millipore Water Purification System, Model-Elix, USA), neutralized to $\mathrm{pH} 7$, dialyzed against water at $4^{\circ} \mathrm{C}$ and finally frozen at $-40^{\circ} \mathrm{C}$ for 7 days, and then thawed at $4^{\circ} \mathrm{C}$ for $24 \mathrm{~h}$. Thawed protein solution showed precipitates at the bottom of the container and clear soluble protein at the top, caused by freeze-mediated concentration [4]. This soluble part was passed through Gel Permeation Chromatography (HSPgel AQ 6.0, Waters, USA) to collect the $66 \mathrm{kDa}$ fraction (Supplementary Figure S1), freeze-dried, and used for encapsulation study.

2.3. Synthesis of C-Dots from Oil-and-Protein Spent Meal. Spent meal (10 g) was dispersed in Milli-Q water such that water: meal ratio is $100: 1(\mathrm{v} / \mathrm{w})$. The suspension was refluxed in an oil-bath under magnetic stirring at $171^{\circ} \mathrm{C}$ for $6.8 \mathrm{~h}$ (predicted optimal condition). After the reaction is over, the resultant black solution was centrifuged at $3000 \mathrm{rpm}$ for $10 \mathrm{~min}$ to separate out the unreacted residue; the blackbrownish supernatant was dialyzed against water (using $1 \mathrm{kDa}$ membrane, Himedia, India) and finally dried under vacuum at $40^{\circ} \mathrm{C}$ to obtain $\mathrm{CNP}(\approx 171 \mathrm{mg} / \mathrm{g}$ dry meal $)$.

2.4. Microsphere (MS) Synthesis from CNP. To a stirred $(200 \mathrm{rpm})$ aqueous solution of CNP $(1 \mathrm{mg} / \mathrm{mL})$, acetone was dropped gradually such that acetone : water $=6: 1 \mathrm{v} / \mathrm{v}$. The obtained precipitate was washed with water and then dried at $40^{\circ} \mathrm{C}$.

2.5. Formation of Protein-Loaded Microspheres (PMS). Purified rapeseed protein was dissolved at a concentration of $5 \mathrm{mg} / \mathrm{mL}$ in $0.01 \mathrm{~N} \mathrm{NaOH}$ ( $\mathrm{pH} 11)$. Protein solution $(0.6 \mathrm{~mL})$ was added to $1.2 \mathrm{~mL}$ of aqueous CNP solution $(1 \mathrm{mg} / \mathrm{mL})$. To this agitated mixture, acetone $(\approx 11 \mathrm{~mL})$ was added and the formed precipitate thus was recuperated by filtration. It was gently washed 3 times with distilled water to remove unbound protein from microsphere (MS) surface and then stored at $4^{\circ} \mathrm{C}$. The quantity of protein entrapped in MS was calculated by the difference between the total protein incorporated in the MS formation medium and the quantity of nonentrapped protein remaining in the aqueous suspending medium. Estimation of protein content was performed by Lowry method. The protein loading capacity of MS was calculated as follows:

$$
\begin{aligned}
& \text { Loading capacity } \\
& \qquad=\left[\frac{(\text { total protein }- \text { free protein })}{\text { nanoparticle weight }}\right] \times 100 .
\end{aligned}
$$

2.6. In Vitro Protein Release Study. The release of protein from PMS was determined by the method described by Alonso-Sande et al. [5]. PMS was incubated at $37^{\circ} \mathrm{C}$ in phosphate buffer solution (PBS, $\mathrm{pH}$ 7.4) under mild horizontal agitation. At appropriate time interval, aliquots were filtered and supernatant isolated for estimating protein by Lowry method.

2.7. Effect of Heat Treatment on Protein Solubility. To determine the susceptibility of protein to thermal insolubilization and aggregation, the solubility of free or entrapped protein, before and after heat treatment, was performed. A requisite amount of freeze-dried rapeseed protein or PMS (having equal amount of loaded protein) was dispersed in $0.01 \mathrm{M}$ PBS ( $\mathrm{pH} \mathrm{7.0),} \mathrm{and} \mathrm{then} \mathrm{the} \mathrm{suspension} \mathrm{was} \mathrm{incubated} \mathrm{in}$ thermostated water bath at $100^{\circ} \mathrm{C}$ for $30 \mathrm{~min}$. After the application of heat, the PMS sample was agitated $(120 \mathrm{rpm})$ for $3 \mathrm{~h}$ at $25^{\circ} \mathrm{C}$ to liberate the entrapped protein. Then the suspension was centrifuged at $5000 \mathrm{rpm}$ for $15 \mathrm{~min}$ and the supernatant was filtered through $0.22 \mu \mathrm{m}$ Biofil membrane. The concentration of protein that remained in the filtrate (soluble protein) was determined according to the Lowry method. Likewise, heated solution having only purified rapeseed protein was centrifuged to remove any possible heatcoagulum and filtered through $0.22 \mu \mathrm{m}$ Biofil membrane, and the amount of soluble protein fraction in the filtrate 
was analyzed. PMS and protein samples, without thermal treatment, were used for comparison.

Free sulfhydryl (SH) content of protein, before loading into MS and after extracting from PMS, was assayed by the methods of Tang et al. [6] and Deng et al. [7]. Surface hydrophobicity $\left(S_{0}\right)$ was measured by SDS binding method $[8,9]$. Differential scanning calorimetry (DSC) of dried sample was performed in a DSC-60 (Schimadzu, Japan), using TA-60WS software (Schimadzu, Japan).

2.8. Characterization. High resolution transmission electron microscopy, HRTEM (JEOL, JEMCXII), images along with the selected-area electron diffraction (SAED) pattern were obtained at an accelerating voltage of $200 \mathrm{kV}$.

$\mathrm{X}$-ray diffraction (XRD) measurement was carried out by thin film mode of powdered sample using Rigaku Miniflex model (Japan), operated at $30 \mathrm{kV}$ voltages and a current of $15 \mathrm{~mA}$ with $\mathrm{Cu}$ Ka radiation source $(\lambda=1.54 \AA)$ at a scan rate of $5^{\circ}(2 \theta) \mathrm{min}^{-1}$ over the range of $10-70^{\circ}$.

Thermogravimetric analysis (TGA) curves were collected on a TG 50 model (Shimadzu, Japan). The samples were combusted under nitrogen flow $(10 \mathrm{~mL} / \mathrm{min}$, to avoid thermooxidative reactions) at the temperature ranging from 25 to $600^{\circ} \mathrm{C}$ and at a rate of $3^{\circ} \mathrm{C} / \mathrm{min}$.

Fourier transform infrared (FTIR) spectra were obtained on a FTIR Nicolet Magna 5PC spectrometer (Impact-410, Madison, USA), coupled to a PC with Omnic analysis software and having DTGS (Deuterated Triglycine Sulfate) detector and Nernst Filament as the IR light source. The sample was ground with $\mathrm{KBr}$ powder to form well-defined pellets for IR measurement, with 32 scans from 4000 to $400 \mathrm{~cm}^{-1}$ at a resolution of $4 \mathrm{~cm}^{-1}$.

Micrograph of the sample was obtained using a JSM6390LV scanning electron microscope, SEM (JEOL, Japan), at an accelerating voltage of $15 \mathrm{kV}$. Prior to SEM observation, samples were mounted on stubs with double-sided adhesive tape, followed by coating the samples with a thin layer of gold. Elemental analysis on single particle was carried out using electron dispersive X-ray spectroscopy (EDX, JSM-6390LV) attachment equipped with SEM.

${ }^{1} \mathrm{H}$ - and ${ }^{13} \mathrm{C}$-Nuclear Magnetic Resonance (NMR) spectrums were detected at $400 \mathrm{MHz}$ by a JEOL NMR system (Japan), using the inbuilt DELTA $(\delta)$ software (versionG4.3.6, Japan) provided by the manufacturer.

Ultraviolet-visible (UV-vis) absorption spectrum of aqueous CNP solution $(0.1 \mathrm{mg} / \mathrm{mL})$ was recorded on a UV-vis spectrophotometer (CECIL 7400, 7000 Series, Aquarius).

Photoluminescence (PL) spectrum of aqueous CNP solution $(0.1 \mathrm{mg} / \mathrm{mL})$ was measured on a photoluminescent spectrophotometer (Model LS 55, Perkin Elmer, Singapore PTE Ltd., Singapore). Intrinsic fluorescence emission spectrum was recorded by exciting protein solution $(2 \mathrm{mg} / \mathrm{mL})$ at $290 \mathrm{~nm}$, after calibrating the background with Milli-Q water [10].

2.9. Antioxidant Activity. Antioxidant activity was measured by the 2,2-diphenyl-1-picrylhydrazyl (DPPH) radical method. Briefly, $3 \mathrm{~mL}$ of sample solution was mixed with $1 \mathrm{~mL}$ of $1 \mathrm{mM}$ methanolic solution of DPPH. The mixture was then vortexed and incubated in dark at ambient temperature for $30 \mathrm{~min}$. The absorbance was measured at $517 \mathrm{~nm}$ in UV-vis spectrophotometer. The DPPH scavenging percentage was calculated using the following formula:

$$
\text { Scavenging activity }(\%)=\frac{\left\{\left(A_{D}-A_{S}\right) \times 100\right\}}{A_{D}},
$$

where, $A_{D}$ and $A_{S}$ are the absorbance of the DPPH solution and the sample, respectively.

2.10. Hemolytic Activity Assay. Hemolytic activity assay was performed according to our earlier report [3]. Briefly, fresh goat blood from a slaughter-house was collected in a centrifuge tube containing anticoagulant, trisodium citrate (3.2\%), and was centrifuged at $3000 \mathrm{rpm}$ for $10 \mathrm{~min}$. The supernatant was discarded and only the red blood corpuscles (RBCs or erythrocytes) were collected. RBCs were further washed three times with PBS $(\mathrm{pH}=7.4)$. A $10 \%(\mathrm{v} / \mathrm{v})$ suspension of erythrocytes in PBS was prepared and $1.9 \mathrm{~mL}$ of this erythrocyte solution was placed in a $2 \mathrm{~mL}$ centrifuge tube and $0.1 \mathrm{~mL}$ of CNP in PBS (1x, pH 7.4) was added to it. The tubes were then incubated for $1 \mathrm{~h}$ at $37^{\circ} \mathrm{C}$. For comparison, Triton X-100 (0.2\%) and PBS were taken as the positive and negative controls, respectively. After incubation the tubes were subjected to centrifugation at $3000 \mathrm{rpm}$ for $10 \mathrm{~min}$, and finally absorbance of the supernatant was taken at $570 \mathrm{~nm}$ in UV-visible spectrophotometer

$$
\begin{aligned}
& \text { Hemolysis \% } \\
& \quad=\left[\frac{(\text { Sample O.D }- \text { Negative control O.D })}{\text { Positive control O.D }}\right] \times 100 .
\end{aligned}
$$

2.11. Antimicrobial Activity. Antimicrobial activity was tested by well-diffusion method, towards 10 different food-borne pathogens, namely, Staphylococcus aureus (MTCC 3160), Pseudomonas diminuta (MTCC 3361), Yersinia enterocolitica (MTCC 859), Salmonella enterica typhimurium (MTCC 1252), Mycobacterium smegmatis (ATCC 14468), Escherichia coli (MTCC 40), Klebsiella pneumoniae (MTCC 618), Bacillus cereus AMDK1 (KC683896; isolated from fermented mustard Kharoli), Listeria monocytogenes AMDK2 (KF894986; isolated from milk product), and Candida albicans (MTCC 183). Briefly, $100 \mu \mathrm{L}$ of a log-phase culture of the test microbes $\left(10^{7}-10^{8}\right.$ cells as per McFarland standard) was seeded on the surface of Potato Dextrose Agar (for C. albicans) or Tryptone Soya Agar (for S. enterica typhimurium and Y. enterocolitica) or Muller Hinton Agar (for remaining test cultures). Using a sterile borer, $8 \mathrm{~mm}$-diameter wells were punched into the surface. In each plate, $50 \mu \mathrm{L}$ of aqueous sample solution $(1 \mathrm{mg} / \mathrm{mL})$ was loaded in the first well. Water was used as negative control in second well. In the third well, gentamicin sulphate $(2 \mathrm{mg} / \mathrm{mL})$ was used as a positive control for bacteria or nystatin was used $(5 \mathrm{mg} / \mathrm{mL})$ for fungi. The seeded plates were incubated at $37^{\circ} \mathrm{C}$ for $24 \mathrm{~h}$ and the antimicrobial activity was recorded as growth-free inhibition 
zones around the well (diameter, measured in millimetres by a Hi Antibiotic Zone Scale (HiMedia, Mumbai, India)). Studies were performed in triplicate, and the developing inhibition zones were compared with those of reference wells.

Minimal inhibitory concentration (MIC) (the lowest concentration at which there is $100 \%$ inhibition of growth) was determined by the microdilution assay [11]. CNP $(1 \mathrm{mg} / \mathrm{mL})$ was serially diluted with Mueller-Hinton broth inoculated with the aliquots of the respective cell suspension, at a final concentration of $10^{5} \mathrm{CFU} / \mathrm{mL}$. $100 \mu \mathrm{L}$ of each dilution was spread on nutrient agar plate and the seeded plates were incubated by a similar procedure as described above.

2.12. Interaction of CNP with E. coli (MTCC 40). For viewing the interaction of CNP with $E$. coli (model bacterium), the bacterial culture was grown in Luria-Bertani (LB) medium for $18 \mathrm{~h}$ at $37^{\circ} \mathrm{C}$ on a rotary shaker at $150 \mathrm{rpm}$. The bacterial cells were then diluted to a cell density of around $10^{8}$ colonyforming units per milliliter $(\mathrm{CFU} / \mathrm{mL})$ with $\mathrm{LB}$ liquid. Bacterial cells were first collected by centrifugation at $6000 \mathrm{rpm}$ for $10 \mathrm{~min}$, and the bacterial pellets were washed three times with saline solution $(0.85 \% \mathrm{NaCl})$ to remove residual culture media. The E. coli cells were treated with CNP (untreated cells served as control) for a given time at $37^{\circ} \mathrm{C}$. A sample drop $(5 \mu \mathrm{L})$ was spotted onto a copper grid-supported carbon film and then viewed under TEM at an acceleration voltage of $200 \mathrm{kV}$.

2.13. Ethidium Bromide (EtBr) Exclusion Assay. Plasmid DNA was isolated from previously transformed E. coli DH5 $\alpha$ strain by standard procedure [12]. The DNA was treated with 1,2 , and $3 \mu \mathrm{g}$ of CNP. The CNP-plasmid DNA complex was allowed to interact for $1 \mathrm{~h}$ at $37^{\circ} \mathrm{C}$. The untreated plasmid DNA was taken as the control. Aliquot of reaction mixture was electrophoresed on a $1 \%$ agarose gel in TAE [tris(hydroxymethyl)aminomethane base, glacial acetic acid, and ethylene diamine tetraacetic acid] buffer containing EtBr, for $60 \mathrm{~min}$ at 70 volts. Gels were then visualized under UV light by Gel Doc system (Syngene GBox F13).

2.14. Statistical Analysis. All analyses were performed in triplicate and the mean value was calculated. Analysis of variance (ANOVA) and separation of means were carried out by Tukey test, using SPSS software (version 16.0, SPSS Inc., Chicago, USA), and considered significantly different at $P<0.05$.

\section{Results and Discussion}

3.1. Physicochemical Features of Optimally Synthesized Nanoparticle. TEM images (Figures $1(\mathrm{a})-1(\mathrm{~d})$ ) confirm that the black product thus obtained from HTC is comprised of almost spherical or oval-shaped nanoparticles, whose diameter lied mainly in the range of 24.4-48 $\mathrm{nm}$. Outer morphology of these nanospheres resembled with that of Mosaic Puff-ball fungus (inset of Figure 1(b)) and the HRTEM images (Figures $1(c)-1(d)$ ) clearly revealed ridges and holes on their surfaces. EDX data (Figure 1(e)) further confirms the fact that the asprepared nanoparticles consist of carbon (53.07 wt\%) and oxygen (46.48wt\%), thus termed carbogenic nanospheres. SEM image (Figure 1(f)) indicates that the dried CNP powder is an aggregate of small carbon grain-sized hundreds of nanometers. The entities appear to be nonhomogeneous in size and shape. This asymmetry is probably due to the effect of vacuum drying, because of which the particles formed clusters of varying sizes and shapes [13]. The UV absorption spectrum (Figure $1(\mathrm{~g})$ ) showed a narrow peak at $\sim 257.6 \mathrm{~nm}$ which is consistent with CNPs synthesized from orange juice [14], soy milk [15], ascorbic acid [16], and so forth. This characteristic absorption peak is usually ascribed to the $\pi-\pi^{*}$ transition of nanocarbons [15]. When CNP was excited at $257.6 \mathrm{~nm}$, an emission peak at $\sim 335.6 \mathrm{~nm}$ was observed (Figure $1(\mathrm{~g})$ ). This observation is completely in line with that of Sahu et al. [14].

One current area of research is assembling nanoparticles into multidimensional materials and lattices. In most cases, the nanoparticles precipitate into layered solids or irregular masses; however, it was found that the herein synthesized CNPs can be assembled or precipitated into micrometer-sized spheres by liquid droplet emulsion method-a feature similar to that of CdSe nanoparticles [17]. This method relies on nanoparticles self-assembly and on the interactions between solvents to form sphere shapes. Based on our preliminary experiments, we have observed that solid spheres form when high volume of acetone is added to the aqueous CNP solution (acetone: water $\geq 6: 1 \mathrm{v} / \mathrm{v}$ ) under agitation. Acetone was included in the analysis because it is one of the most widely used solvents in the nanoprecipitation methods [13]. Thus when acetone is abundant, it encapsulates droplets of water, which contain CNPs. Diffusion of the water away from the CNPs causes the particles to prefer to adhere to each other, since they are not soluble in acetone, and finally nanoprecipitation occurs (Supplementary Figure S2). The acetone was retrieved from water by vacuum distillation for reuse. SEM and TEM images (Figures 2(a)-2(b)) clearly revealed that the entities, prepared by liquid droplet emulsion, are spherical and their diameters are mainly distributed in the range of $160-266 \mathrm{~nm}$ (>100 nm, thus termed as "microspheres" (MS)). The net yield of MS from CNP $(1 \mathrm{mg} / \mathrm{mL})$ was $87 \pm 6 \%$. Just after fabricating MS, all particles existed in the colloidal form which resulted in a stable suspension. However, as time went on, the suspension formed loose networks of flocs that settle rapidly. The sediment of the particles was easy to redisperse. MS was found to be stable to vigorous stirring in solvents, centrifugation, and vacuum drying. Once formed, it was difficult to dissociate MS back into its constituent CNPs.

FTIR spectra were acquired to gain further structural insights and surface state of both CNP and MS. In CNP (Figure 2(c)), stretching frequency at 678.38, 1091.17, 1238.35, 1371.99, 1419.36, 1637.57, 1700.19, 2090.98, and $3366.54 \mathrm{~cm}^{-1}$ indicated the presence of olefinic $\mathrm{C}-\mathrm{H}$ (out-of-plane), $\mathrm{C}-\mathrm{O}$, carboxylate group, $\mathrm{N}-\mathrm{H},-\mathrm{OH}$ (in-plane bend), $\mathrm{C}=\mathrm{O}$, aryl aldehyde, aliphatic $\mathrm{C}-\mathrm{H}$, and $-\mathrm{OH}$ stretch, respectively. It is possible that presence of different oxygenous hydrophilic functional groups imparts excellent water solubility to CNP [14-16]. In case of MS (Figure 2(d)), the vibrations at 727.44, 


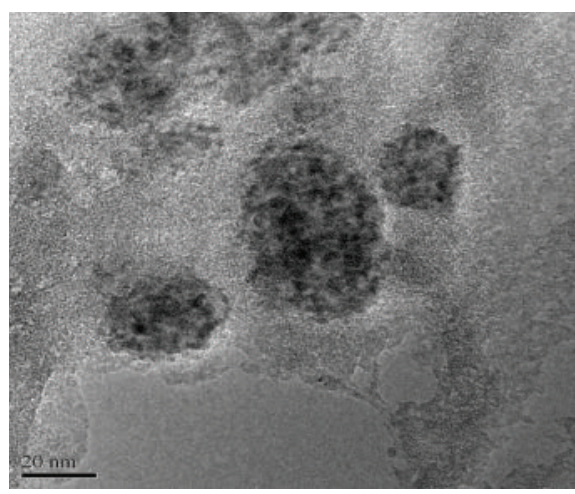

(a)

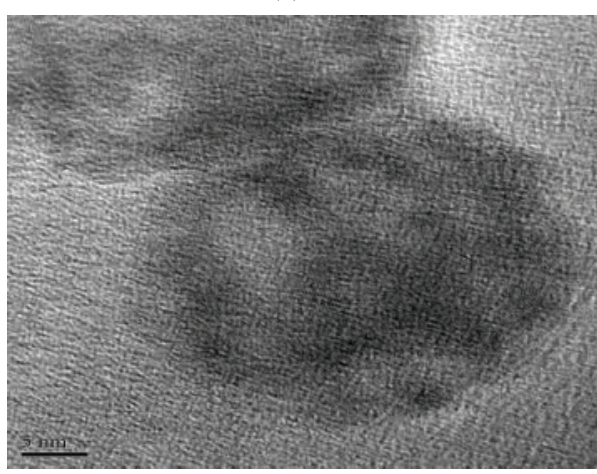

(c)

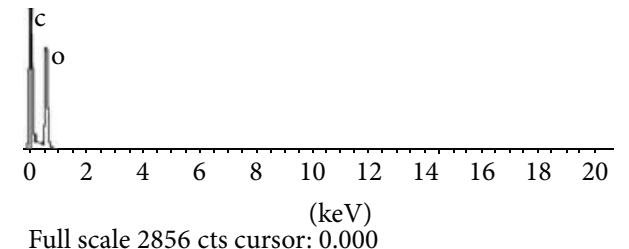

Full scale 2856 cts cursor: 0.000

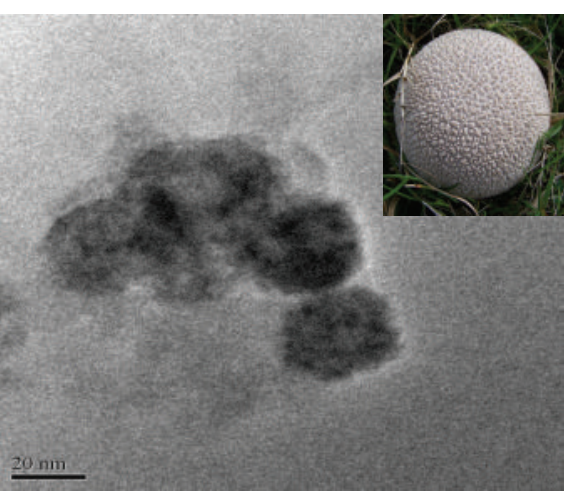

(b)

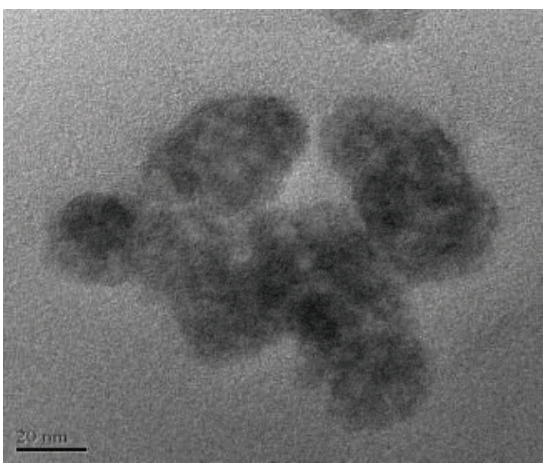

(d)

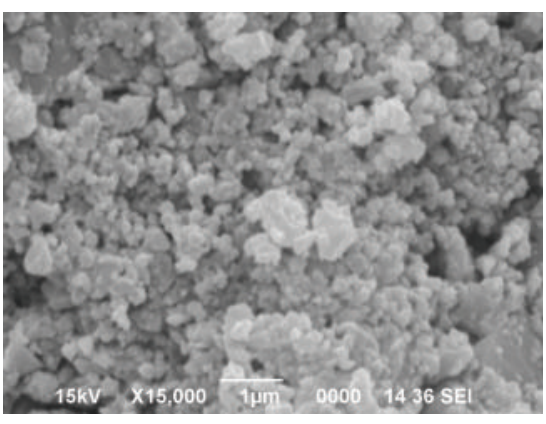

(f)

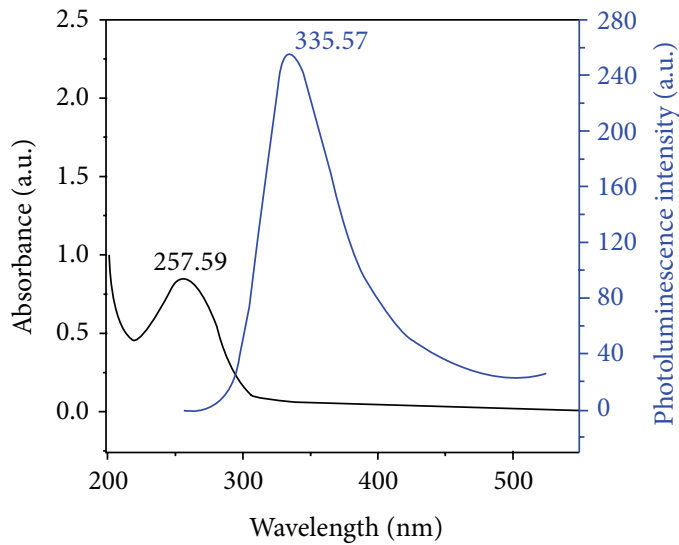

(g)

Figure 1: (a)-(d) TEM images (e) EDX (f) SEM image (g) UV absorption and PL emission spectra $\left(\lambda_{\text {ex }}=257.6 \mathrm{~nm}\right)$ of as-synthesized CNP. Scale bar in (a), (b), and (d) represents $20 \mathrm{~nm}$ and that in (c) represents $5 \mathrm{~nm}$. 


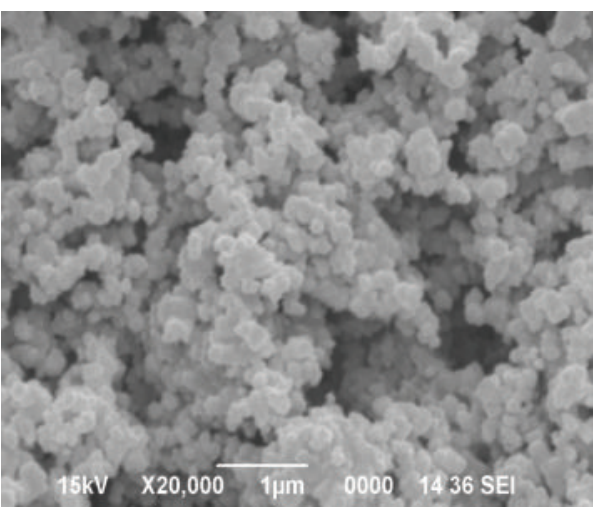

(a)

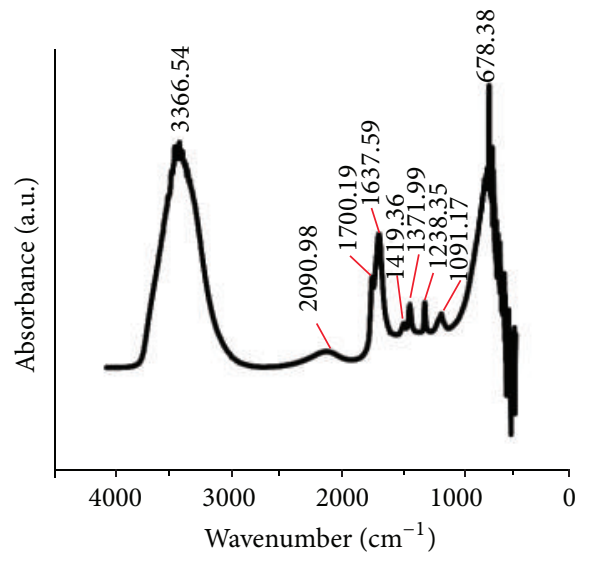

(c)

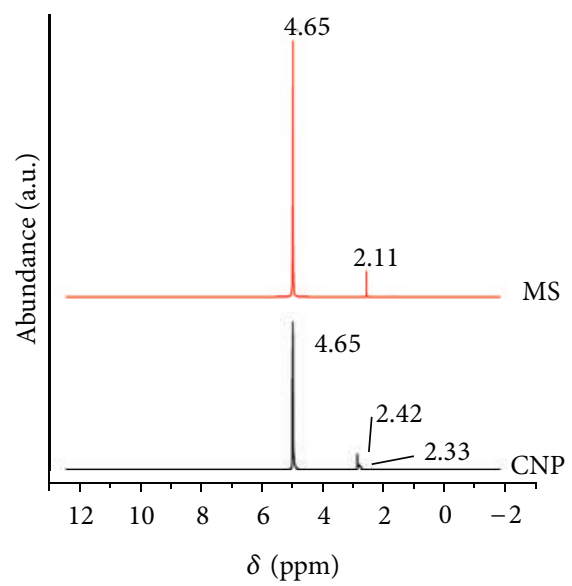

(e)

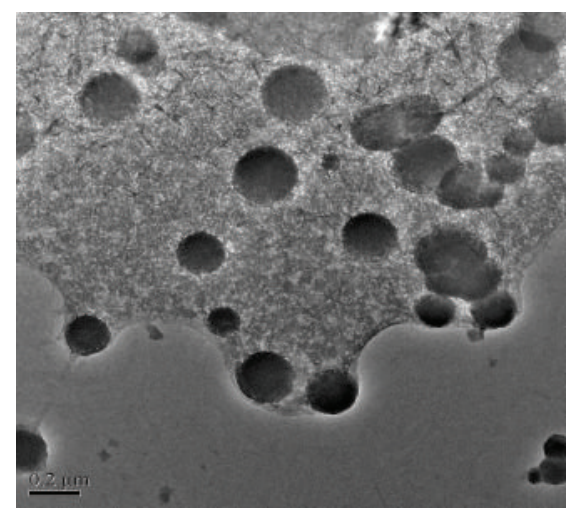

(b)

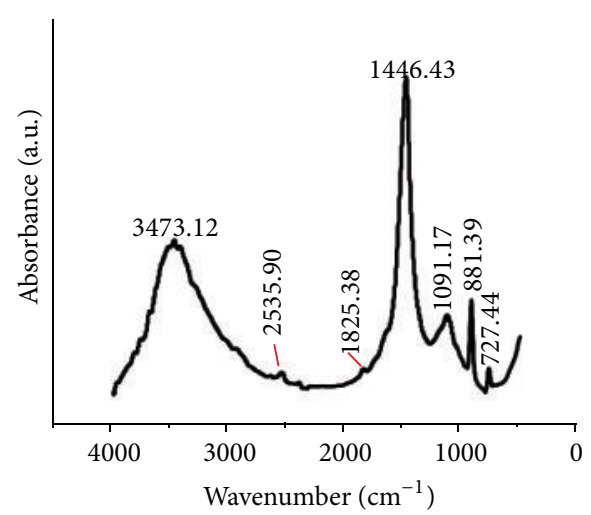

(d)

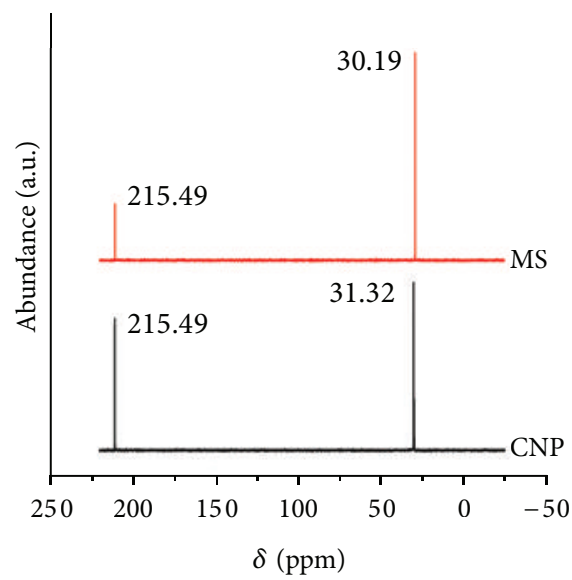

(f)

Figure 2: (a) SEM (b) TEM image of MS; FTIR spectrum of (c) CNP (d) MS; (e) ${ }^{1} \mathrm{H}-\mathrm{NMR}$ (f) ${ }^{13} \mathrm{C}-\mathrm{NMR}$ spectra of CNP and MS.

881.39, 1091.17, $1446.43,1825.38,2535.90$, and $3473.12 \mathrm{~cm}^{-1}$ designated the presence of methylene $\left(-\mathrm{CH}_{2}-\right)$, out-of-plane $\mathrm{C}-\mathrm{H}$ bend, $\mathrm{C}-\mathrm{O}, \mathrm{C}=\mathrm{C}$ ring stretch of benzene derivatives, vinyl $\left(-\mathrm{CH}=\mathrm{CH}_{2}\right), \mathrm{C}-\mathrm{H}$, and $-\mathrm{OH}$ group, respectively. The difference between the two spectra is that the MS has reduced -OH groups and a well-defined recognizable stretch at $1446.43 \mathrm{~cm}^{-1}$, compared to CNP. The band at $1446 \mathrm{~cm}^{-1}$ is one of the typical bands for the $\mathrm{C}=\mathrm{C}$ ring stretch of benzene and its derivatives [18]. Derived from this fact, it is feasible to believe that MS, with aromatic surface moieties, is less soluble in aqueous medium. All these facets suggest the possibility of new interactions and cross-links between individual CNPs during MS formation. NMR spectra highlighted the presence of two different kinds of chemical environments or regions, which are discussed as follows. In ${ }^{1} \mathrm{H}-\mathrm{NMR}$ spectra (Figure $2(\mathrm{e})), \delta=2.1 \mathrm{ppm}$ indicates methyl $\left(-\mathrm{CH}_{3}\right)$ protons 
in CNP and $\delta=2.3-2.4 \mathrm{ppm}$ signifies methylene $\left(-\mathrm{CH}_{2}-\right)$ protons in MS. Proton signal at $\delta=4.65 \mathrm{ppm}$ is for vinylic groups [18], which seems to be higher in MS in comparison with CNP. In ${ }^{13} \mathrm{C}$-NMR spectra (Figure 2(f)), $\delta=20-80 \mathrm{ppm}$ is noted for sp ${ }^{3}$ carbons, whereas the peak at $\delta=215.49 \mathrm{ppm}$ depicts ketonic or $\mathrm{C}=\mathrm{O}$ linkage [19]; the latter seems to be more pronounced in CNP than MS. These observations corroborate with those of FTIR. XRD pattern of both the samples show a broad hump within $23^{\circ}-33^{\circ}$ (Supplementary Figure S3(A)), which is attributable to amorphous carbon phase. This agrees well with the SAED images (Supplementary Figure S3(B)-S3(C)).

With a premonition to detect the antioxidative potential of the prepared CNP and MS, DPPH-radical scavenging activity was performed. At $50 \mu \mathrm{g} / \mathrm{mL}$ concentration, radical quenching activity of CNP was $46.91( \pm 2.83) \%$ and that of MS was only $7.32( \pm 0.11) \%$, which is probably due to its poor solubility. This noble facet of CNP requires detailed study to unveil its underlying mechanism; nevertheless, from the knowledge gained so far, it could be explained that the scavenging behavior of CNP may be ascribed to its nanosize with increased surface-to-volume ratio (providing more available reaction sites) and also to the presence of different surface functional moieties, which tends to interact with and reduce DPPH species, similar to that reported for its other counterparts like fullerenes and carbon nanotubes $[20,21]$.

3.2. Hemocompatibility of CNP and MS. The broader use of CNP and subsequent mass production will lead to greater possibilities for its interaction with humans. It is therefore important to determine the toxicity of CNP and MS on mammalian RBC, as it would eventually come in direct/indirect contact with blood as soon they are exposed to the host's body. According to the criterion in the ASTM E2524-08 standard (Standard test method for analysis of hemolytic products of nanoparticles), percent hemolysis $>5 \%$ indicates the test material to be toxic to RBC; this criterion was exceeded at CNP concentration of $100 \mu \mathrm{g} / \mathrm{mL}$ (Figure 3(a)). MS demonstrated reduced or almost no hemolytic activity, which may be due to its poor solubility. Also, photographs showing precipitated RBCs at the end of the hemolysis experiment are given in Figures 3(b)-3(c). The red colour of the released hemoglobin from damaged cells is clearly observable for positive control and $100 \mu \mathrm{g} / \mathrm{mL}$ CNP sample. For MS, the supernatants were almost colourless at all the tested concentrations. There was no hemolysis for CNP at lower concentration. Thus, CNP exerts toxicity to RBC in a dose-dependent manner, while MS can be considered nontoxic even at higher concentration.

\subsection{MS as Functional Ingredient (for Protein Encapsulation).} During the past few decades, there has been considerable interest in the use of nanoparticles as potential drug delivery systems. Proteins, being one of the important biomolecules in the medical, pharmaceutical, and food fields, confront major challenges during processing due to their physical and chemical instability. In this paper, we present the use of MS to encapsulate purified rapeseed protein. The design principle of the protein-loaded MS (PMS) was inspired from the self-assembling nature of CNPs in presence of acetone. Protein loading capacity was calculated to be $68 \pm 6 \%$ and the diameter of PMS varied within 166.33-266.67 nm (Figures 3(d)-3(e)). Inset of Figure 3(e) shows the release profile of protein from PMS into PBS at $37^{\circ} \mathrm{C}$. The mechanism of release was simple diffusion of the protein molecules from the particle. More specifically, it was assumed that the presence of high ion concentrations in the buffer interfered with the electrostatic interactions that retained the protein within the particles, causing its initial burst release [5]. The released protein reached a plateau after $20 \mathrm{~min}$. The slower release percentage of remaining protein could be attributed to the possible interaction between residual protein and functional groups of MS (such as hydrogen bonding) [5].

Carbon-based nanoparticles are known to exhibit incredible thermal stability $[22,23]$. We hypothesize that CNPderived MS would be an adequate vehicle/carrier of labile protein against thermal degradation. To justify this possibility, we compared the thermal behavior of CNP, MS, and purified rapeseed protein with that of PMS (Figure 3(f)). The thermogram of CNP exhibited a 2-step degradation pattern with the initial degradation $\left(<100^{\circ} \mathrm{C}\right)$ ascribed to the moisture loss, while the final degradation $\left(271.83-309.57^{\circ} \mathrm{C}\right)$ was associated with the decomposition of oxygen-containing groups [22]. Except MS, thermograms of all other samples followed similar one-step degradation pattern. It is worthy to mention that the net weight loss of MS during analysis was found to be only $\sim 6.7 \%$, which points to its high resistance to thermal degradation; whereas those of CNP, protein, and PMS were $\sim 22.63, \sim 80.58$, and $45.65 \%$, respectively. The reduced mass loss (char formation) of PMS compared to that of purified protein proves MS as potent thermoinsulator for proteinaceous materials, a property similar to that of carbon nanotubes [23]. Our results are partly in accordance to those reported by Noritomi et al. [24], where thermal stability of lysozyme protein was found to increase after adsorbing on biomass charcoal powder. Proteins efficacy is often compromised by their thermal aggregation, resulting in poor water solubility and lower absorption in human body. For testing such aggregation, susceptibility of rapeseed protein to thermal insolubilization, before and after loading, was perceived from Figure $3(\mathrm{~g})$. The soluble protein content of freeze-dried rapeseed protein prior to heat treatment was considered as $100 \%$. Before the application of heat, about $84 \%$ of loaded protein could be retrieved from PMS as soluble fraction. After heating the samples for $30 \mathrm{~min}$ at $100^{\circ} \mathrm{C}$, the solubility of rapeseed protein showed a marked decrease. Only $\sim 23.8 \%$ of soluble fraction was recovered from heattreated rapeseed protein, whereas heat-treated PMS gave a soluble protein fraction of $39.1 \%$, denoting that a resistant crust and consequently a resistant structure was created, which can protect thermolabile substances such as protein to a considerable extent during processing. The above statement is supported with their DSC thermograms (Supplementary Figure S4). Endothermic transition was clearly visible in pristine protein sample (before heating), which was completely lost after heat application. Transition temperature $\left(T_{d}\right)$ of 


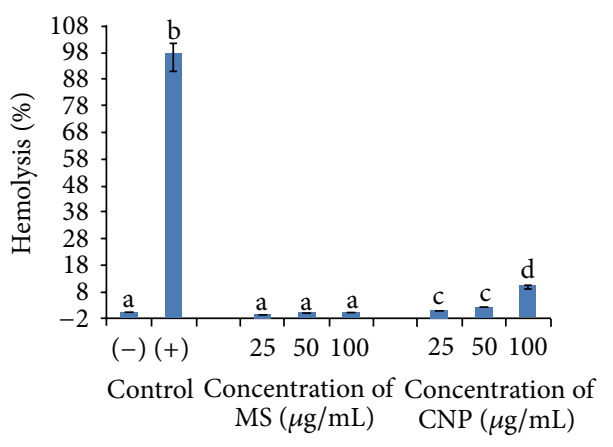

(a)

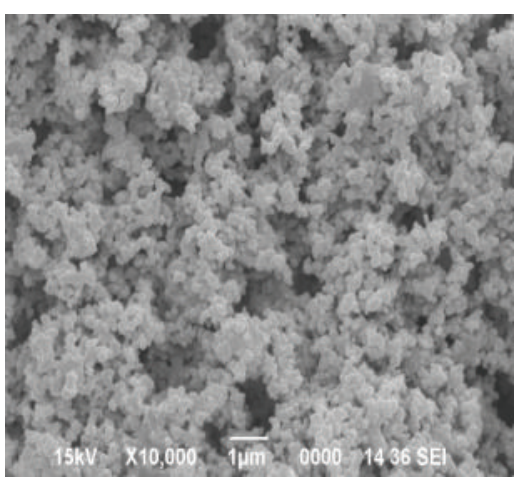

(d)

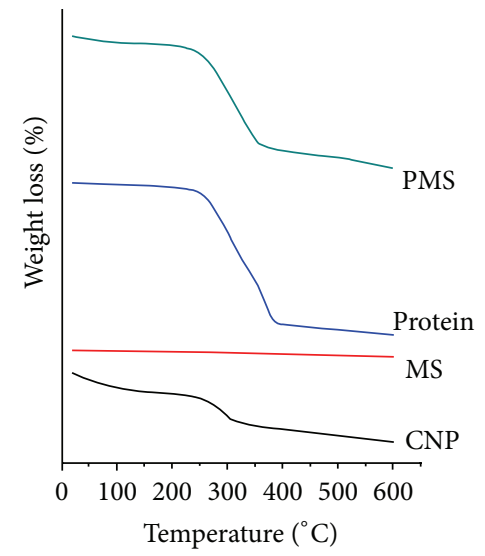

(f)

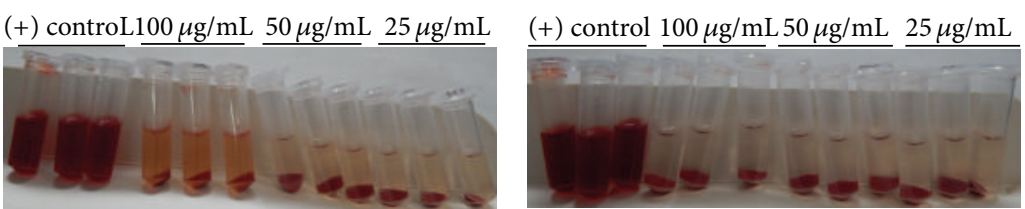

(b)

(c)

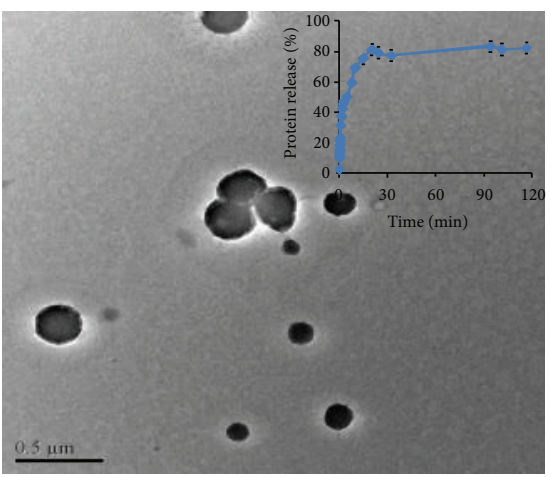

(e)

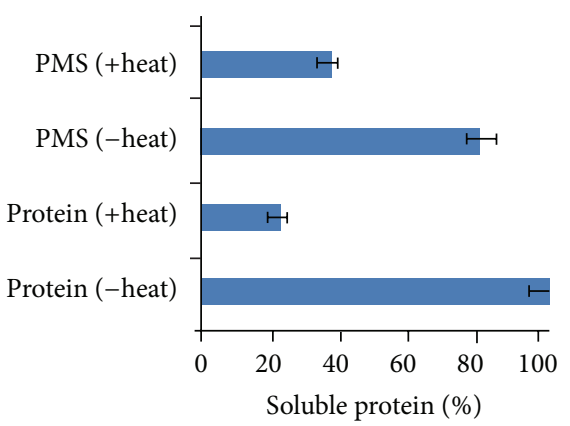

(g)

FIgURE 3: (a) Hemolysis percentages of CNP and MS at different concentrations. Data generated from three independent experiments. Bars with different letters are significantly different at $P<0.05$; (b)-(c) Photographs of RBCs treated with CNP and MS at different concentrations. $(-)$ and $(+)$ controls are the RBCs in PBS and Triton-X, respectively; (d) SEM (e) TEM image (inset showing protein release profile) of PMS; (f) TGA pattern of CNP, MS, purified rapeseed protein, and PMS; (g) Effect of heat on protein solubility in presence or absence of MS as entrapment vehicle.

protein extracted from PMS was found to be higher relative to that of pristine protein. Taking into account the data from FTIR (discussed later), the rise in $T_{d}$ can be associated with its compact structure, probably caused by acetone and heat treatment. The extract from PMS seemed to consist of considerably structured-preserved protein, as its DSC profile showed discernible sign of endothermic transition (Supplementary Figure S4).

Further, the effect of CNP complexation and subsequent PMS formation on the conformational features of loaded protein has been studied by FTIR, free SH groups, $S_{0}$, and intrinsic fluorescence assay [25]. The pristine freeze-dried protein (prior to loading into MS) and the soluble protein fraction extracted from PMS presented identical FTIR spectroscopic patterns, with no significant differences in the major bands (Figures 4(a) and 4(b)). The Amide A band $\left(\sim 3300 \mathrm{~cm}^{-1}\right)$ and Amide $\mathrm{B}\left(\sim 3000 \mathrm{~cm}^{-1}\right)$ are attributed fundamentally to $\mathrm{N}-\mathrm{H}$ stretching of protein vibrations, with contribution from $\mathrm{O}-\mathrm{H}$ stretching of intermolecular hydrogen bonding. Amide I band, located in the region of $\sim 1662 \mathrm{~cm}^{-1}$, 


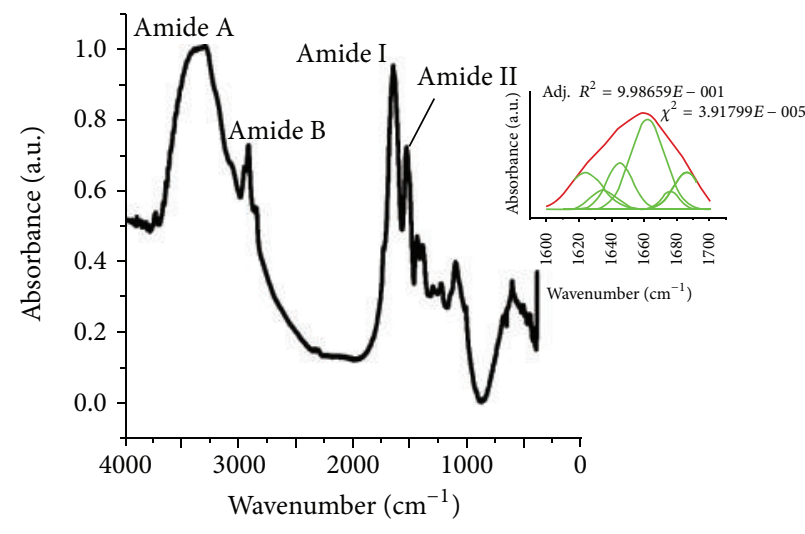

(a)

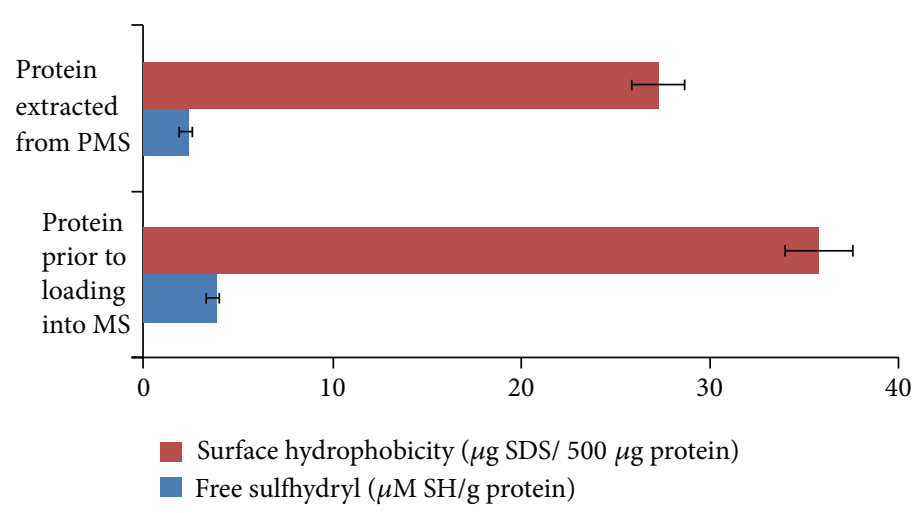

(c)

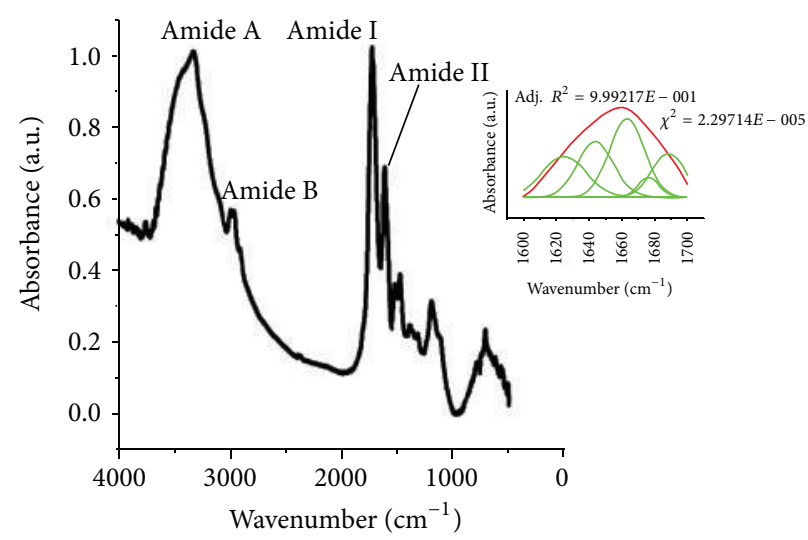

(b)

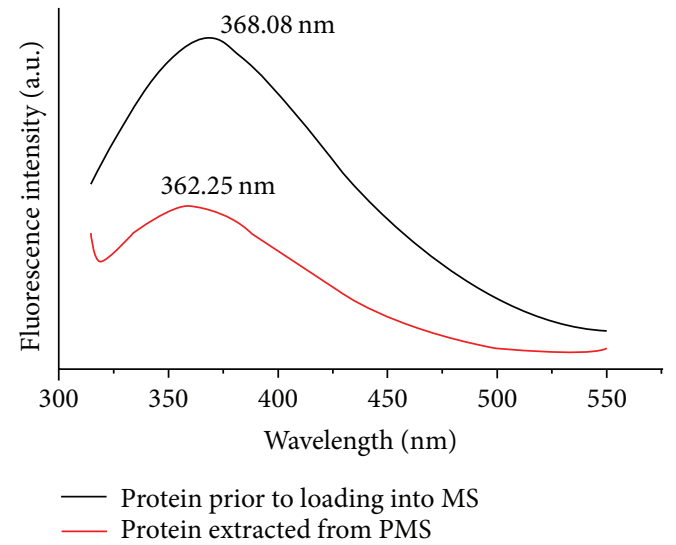

(d)

FIGURE 4: FTIR spectra of protein before (a) and after (b) loading into MS (inset showing the Gaussian curve-fitted Amide I region of their respective spectrum). (The red line represents the protein IR spectra, which coincide with the results of the Gaussian curve-fitting. Green lines are the individual Gaussian bands fitted to the spectra. Spectral correlation coefficients between the original IR spectra and the Gaussian curve-fitting were calculated (adjusted $R^{2}$ ) and error of the estimate is represented as Chi-square value $\left(\chi^{2}\right)$ ); (c) Difference in free SH and $S_{0}$ and (d) intrinsic fluorescence emission spectra of the protein before and after loading into MS.

arises predominantly from $\mathrm{C}=\mathrm{O}$ stretching vibrations, being weakly coupled with in-plane $\mathrm{N}-\mathrm{H}$ bending and $\mathrm{C}-\mathrm{N}$ stretching vibrations [26]. Amide II band $\left(\sim 1540 \mathrm{~cm}^{-1}\right)$ represents $\mathrm{N}-\mathrm{H}$ bending vibrations coupled to $\mathrm{C}-\mathrm{N}$ stretching. As spectral changes in Amide I region $\left(1700-1600 \mathrm{~cm}^{-1}\right.$ ) have been widely used for the analysis of secondary structures of proteins, Gaussian curve-fitting was performed by secondorder derivative spectra in Amide I region of the two samples (Inset of Figures 4(a) and 4(b)). Correlation coefficient (Adj. $R^{2}$ ) between the original and fitted spectra was $\geq 0.999$, and the error of estimate (Chi-square value) was $\leq 3.92 \times$ $10^{-5}$. Schmidt et al. [27] found rapeseed napin protein to be primarily composed of $\alpha$-helices (45-57.9\%) and $\beta$-sheets (7-15.3\%) as a function of $\mathrm{pH} 3-12$. These data are partly consistent with the present result, where pristine protein had $59.2 \% \alpha$-helix and $36.85 \% \beta$-sheet, and soluble protein extracted from PMS showed $55.77 \% \alpha$-helix and $41.81 \% \beta$ sheet. Decrease in $\alpha$-helix, with concomitant rise in $\beta$-sheet, indicates a less organized structure of the latter. The protein extracted from PMS also presented lower free SH group and $S_{0}$ relative to those of pristine protein (Figure $4(\mathrm{c})$ ). This can be the direct consequence of organic solvent (acetone used during PMS preparation) on protein. As known, organic solvent preferentially interacts with protein via hydrophobic interactions [25], altering the spatial distribution and accessibility of $\mathrm{SH}$ groups. Reduction in $S_{0}$ is congruent with lower value of thiol content, which in-turn indicates the blocking off or burial of hydrophobic moieties back into the protein core, possibly due to conformational changes induced by acetone. This presumption is further substantiated with the intrinsic emission fluorescence spectra (Figure 4(d)), which is usually dominated by tryptophan (Trp) residues of the protein involved. Protein extracted from PMS presented reduction in fluorescence intensity compared to pristine protein, together with a blue shift in $\lambda_{\max }$ (movement towards lower wavelength). This implies less polar surroundings of Trp; that is, Trp residues are shielded from bulk water medium or moved closer to more hydrophobic core [28]. These results indicated that the encapsulation of protein into PMS caused slight perturbation in its secondary and tertiary structures during preparation step mainly by acetone. Nevertheless, the effect is less severe than that caused by the 


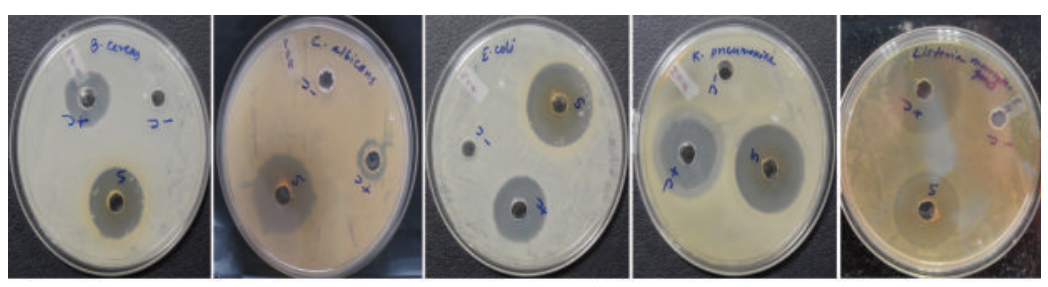

(i)

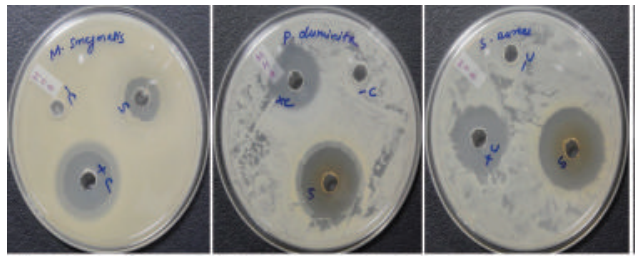

(vi) (vii) (viii)

(a) (iv)

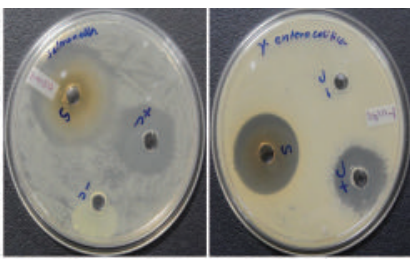

(ix)

(x)

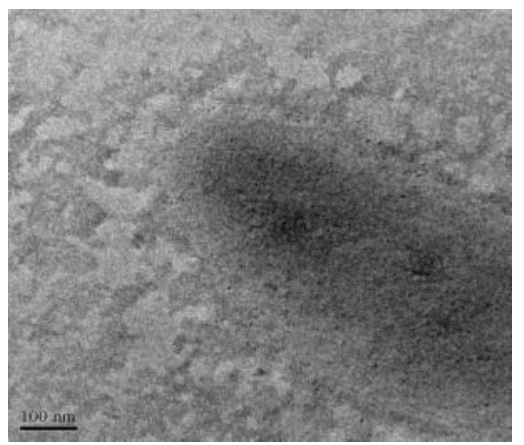

(c)

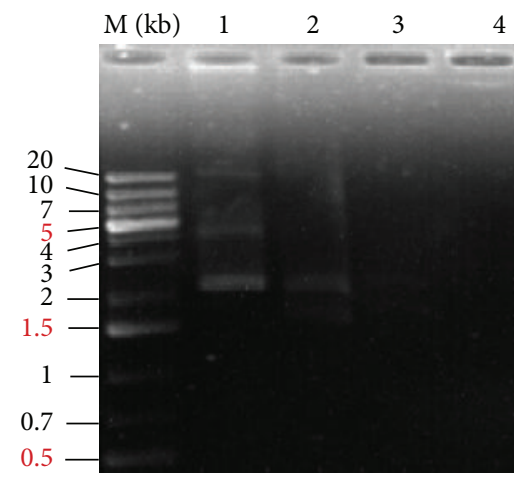

(e) (d)

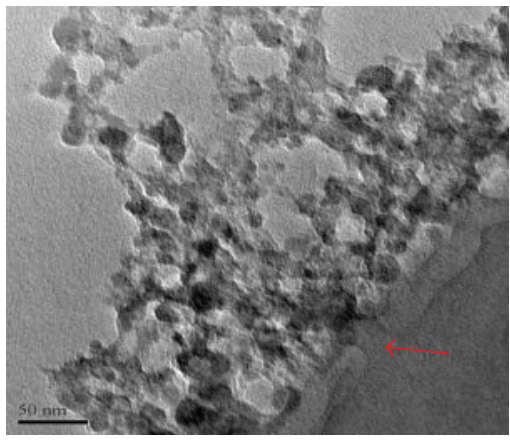

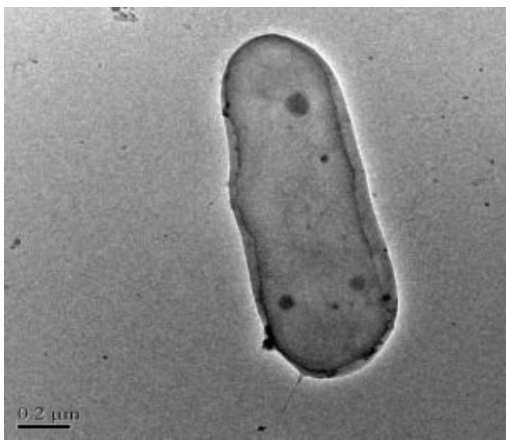

(b)

Figure 5: (a) (i) B. cereus AMDK1 (KC683896), (ii) C. albicans (MTCC 183), (iii) E. coli (MTCC 40), (iv) K. pneumoniae (MTCC 618), (v) L. monocytogenes AMDK2 (KF894986), (vi) M. smegmatis (ATCC 14468), (vii) P. diminuta (MTCC 3361), (viii) S. aureus (MTCC 3160), (ix) S. enterica typhimurium (MTCC 1252), and (x) Y. enterocolitica (MTCC 859). (-c) and (+c) represent water as negative control and gentamicin sulphate (for bacteria) or nystatin (for fungi) as positive control. (s) indicates sample (CNP); (b) untreated and (c) CNP-treated E. coli viewed under TEM; (d) HRTEM image of CNP-treated E. coli showing pit formation in cell membrane; (e) electrophoretic mobility of CNP-plasmid DNA complex. Lane M of the gel shows GeneRuler $1 \mathrm{~kb}$ Plus DNA ladder (Fermentas).

water-in-oil-in-water double emulsion technique, which is a common approach to prepare nanoparticles loaded with proteins [29]. Future investigation should focus on selecting a solvent system or a complexing agent which would not perturb the conformational structure of the protein.

3.4. CNP as Antimicrobial Ingredient. Recently, research attention has been drawn towards the antibacterial activity of carbon based nanostructures and their hybrids. CNP was found to be active against all the microbes used for the antimicrobial test. The mean zone of inhibition (Figure 5(a)) clearly demonstrated the potential activity of CNP against the tested microbes. The results are summarized in Table S1. It was very active against $S$. aureus, $P$. diminuta, $Y$. enterocolitica, S. enterica typhimurium, C. albicans, and E. coli and was moderately active against $B$. cereus AMDK1, L. monocyto- 
genes AMDK2, and K. pneumonia, and it showed low activity against $M$. smegmatis. MIC of CNP against gram positive strains was found to be from 31 to $62 \mu \mathrm{g} / \mathrm{mL}$ whereas that against gram negative indicator strains ranges from 7 to $15 \mu \mathrm{g} / \mathrm{mL}$. These differences in the susceptibility of the test organisms to CNP could be attributed to a variation in the rate of the nanoparticle penetration through the cell wall and cell membrane structures. The effect of MS on the selected strains was found to be negligible, most likely due to the difficulty of dispersing MS in water and also because of its larger size. As the size of carbon particles decreases down to nanoscale range their antimicrobial activity increases because of their larger surface area per unit volume and facilitated cell membrane penetration ability [30]. Despite this general agreement, a mechanistic explanation of its bactericidal activity is still elusive. Among the current hypothesized disruption mechanisms of intracellular metabolic pathways, oxidative stress, and physical membrane damage causing rupture, the generations of reactive oxygen species and oxidative stress are the most developed paradigms [30]. We further relied on TEM to dissect the interactions between CNP and E. coli (used as a bacterium model), with a hope to provide some fundamental clues towards a rational understanding of its antibacterial behavior. As can be seen from Figure 5(b), untreated E. coli (as control) possessed a typical rod-like shape, a well-defined cell wall, and an evenly distributed interior content, evidencing a structural integrity. In sharp contrast to the control, a significant morphological change occurred to the E. coli cell after being incubated with CNP for $2 \mathrm{~h}$ (Figure 5(c)). The cell wall and membrane were then damaged in presence of CNP due to its strong affinity to the cell surface, and finally the whole cell became distorted and collapsed into unstructured pieces. In addition, HRTEM image shows a clear binding of CNP on the bacterial surface, which accounted well for the bacterial growth suppression in presence of this nanomaterial. This was closely associated with the formation of "pits" on the bacterial surface (marked by arrow in Figure 5(d)), probably followed by a discharge of intracellular substances to the surrounding medium.

The antimicrobial activity of nanomaterials may be mediated by their action on plasmid DNA [31]. In an attempt to justify this possibility, we studied the degree of plasmid DNA condensation by CNP, using EtBr exclusion assay, for which the migration of the CNP-plasmid DNA complexes by agarose gel electrophoresis was evaluated. The fluorescent bands observed in Lane 1 of Figure 5(e) originate from intercalation of adequate $\mathrm{EtBr}$ with free (uncomplexed) plasmid DNA (as control). As the condensation of plasmid DNA becomes higher, by increasing CNP concentration, the availability of DNA bases for EtBr intercalation decreases (excludes EtBr), thereby quenching the fluorescence signal [32]. This might be the probable cause for an overall decrease in the fluorescence intensity of the DNA bands in Lane 2 as compared to control (Lane 1). Because of this reason, it was not possible to observe fully condensed plasmid DNA participating in the CNP:DNA complexes, especially in Lane 3 and 4, indicating even further reduction in the amount of free DNA available for intercalation. Typically, this assay is used to study the migration of different types of DNA conformations as indicated by a shift in their migration rate. With respect to the control, there was a downward shift in the free DNA bands when CNP was added to the gel (Lane 2 versus Lane 1). This is most likely caused by the supercoiling of the plasmid DNA, in presence of CNP, the accumulation of which suppresses the transcription [33], and eventually resulting in cell death. It is worth stressing that these observations and explanations are still very preliminary and further investigations and more microbial experiments are definitely needed in the future to probe these processes from a molecular basis. Nevertheless, from the knowledge gained so far, it can be envisioned that CNP, with its added benefits of ecofriendliness and dose-dependent hemocompatibility, may be useful for inhibiting microbial attachment and biofouling formation in water treatment and food processing plants.

\section{Conclusion}

In summary, we have shown that carbon nanomaterials with rich functionalities can be spontaneously synthesized from "oil-and protein" spent rapeseed meal waste by HTC. The obtained CNP was found to be multifunctional (considerable antioxidative potential, dose-dependent hemocompatibility, and excellent antimicrobial activity). The ability of CNP to disrupt the bacterial membrane structures and the accompanying condensation of plasmid DNA by complexation are the most likely reasons for its lethal action. The ultimate impact of this work may be its direct implementation as a cheap point-of-use microbiocide for deactivating pathogens in water purification or food processing plants. We also proposed the uniqueness of the herein synthesized CNPs to form a sphere with micrometer diameter. These spheres provide remarkable protection to the entrapped protein against thermodegradation and aggregation. Together with its novel hemocompatible feature, CNP-derived MS can be an attractive candidate as an efficacy enhancer in pharmaceutical, cosmetics, and food products.

\section{Conflict of Interests}

The authors declare that there is no conflict of interests regarding the publication of this paper.

\section{Acknowledgments}

MDP is thankful to DST-INSPIRE and AKM acknowledges UGC-RGNF for meritorious fellowship.

\section{References}

[1] M. Saxena and S. Sarkar, "Synthesis of carbogenic nanosphere from peanut skin," Diamond and Related Materials, vol. 24, pp. $11-14,2012$.

[2] X. X. Zhang, Z. Q. Li, G. H. Wen, K. K. Fung, J. Chen, and Y. Li, "Microstructure and growth of bamboo-shaped carbon nanotubes," Chemical Physics Letters, vol. 333, no. 6, pp. 509$514,2001$.

[3] M. Das Purkayastha, S. Das, A. K. Manhar, D. Deka, M. Mandal, and C. L. Mahanta, "Removing anti-nutrients from rapeseed 
press-cake and their benevolent role in waste cooking oilderived biodiesel: conjoining the valorization of two disparate industrial wastes," Journal of Agricultural and Food Chemistry, vol. 61, no. 45, pp. 10746-10756, 2013.

[4] K. Morita and M. Shimoyamada, "Proposal of mechanism of the freeze-thaw fractionation of 7S and 11S globulins in soymilk," Food Chemistry, vol. 140, no. 1-2, pp. 39-43, 2013.

[5] M. Alonso-Sande, M. Cuña, C. Remuñán-López, D. TeijeiroOsorio, J. L. Alonso-Lebrero, and M. J. Alonso, "Formation of new Glucomannan-chitosan nanoparticles and study of their ability to associate and deliver proteins," Macromolecules, vol. 39, no. 12, pp. 4152-4158, 2006.

[6] C.-H. Tang, X.-Y. Wang, F. Liu, and C.-S. Wang, "Physicochemical and conformational properties of buckwheat protein isolates: influence of polyphenol removal with cold organic solvents from buckwheat seed flours," Journal of Agricultural and Food Chemistry, vol. 57, no. 22, pp. 10740-10748, 2009.

[7] Q. Deng, L. Wang, F. Wei et al., "Functional properties of protein isolates, globulin and albumin extracted from Ginkgo biloba seeds," Food Chemistry, vol. 124, no. 4, pp. 1458-1465, 2011.

[8] B. Hiller and P. C. Lorenzen, "Surface hydrophobicity of physicochemically and enzymatically treated milk proteins in relation to techno-functional properties," Journal of Agricultural and Food Chemistry, vol. 56, no. 2, pp. 461-468, 2008.

[9] B. Hiller and P. C. Lorenzen, "Effect of phosphatase/transglutaminase treatment on molar mass distribution and technofunctional properties of sodium caseinate," LWT-Food Science and Technology, vol. 42, no. 1, pp. 87-92, 2009.

[10] Y. Liu, G. Zhao, J. Ren, M. Zhao, and B. Yang, "Effect of denaturation during extraction on the conformational and functional properties of peanut protein isolate," Innovative Food Science and Emerging Technologies, vol. 12, no. 3, pp. 375-380, 2011.

[11] I. Wiegand, K. Hilpert, and R. E. W. Hancock, "Agar and broth dilution methods to determine the minimal inhibitory concentration (MIC) of antimicrobial substances," Nature Protocols, vol. 3, no. 2, pp. 163-175, 2008.

[12] T. Maniatis, E. F. Fritsch, and J. Sambrook, Molecular Cloning: A Laboratory Manual, Cold Spring Harbor Laboratory Press, Cold Spring Harbor, NY, USA, 2nd edition, 1989.

[13] S. Galindo-Rodriguez, E. Allémann, H. Fessi, and E. Doelker, "Physicochemical parameters associated with nanoparticle formation in the salting-out, emulsification-diffusion, and nanoprecipitation methods," Pharmaceutical Research, vol. 21, no. 8, pp. 1428-1439, 2004.

[14] S. Sahu, B. Behera, T. K. Maiti, and S. Mohapatra, "Simple onestep synthesis of highly luminescent carbon dots from orange juice: application as excellent bio-imaging agents," Chemical Communications, vol. 48, no. 70, pp. 8835-8837, 2012.

[15] C. Zhu, J. Zhai, and S. Dong, "Bifunctional fluorescent carbon nanodots: Green synthesis via soy milk and application as metal-free electrocatalysts for oxygen reduction," Chemical Communications, vol. 48, no. 75, pp. 9367-9369, 2012.

[16] X. Jia, J. Li, and E. Wang, "One-pot green synthesis of optically $\mathrm{pH}$-sensitive carbon dots with upconversion luminescence," Nanoscale, vol. 4, no. 18, pp. 5572-5575, 2012.

[17] R. G. Harrison, A. L. Washburn, A. T. Pickett, and D. M. Call, "Assembly of CdSe nanoparticles into microspheres by a liquid droplet emulsion process," Journal of Materials Chemistry, vol. 18, no. 31, pp. 3718-3722, 2008.

[18] P. S. Kalsi, Spectroscopy of Organic Compounds, New Age International, New Delhi, India, 2000.
[19] B. De and N. Karak, "A green and facile approach for the synthesis of water soluble fluorescent carbon dots from banana juice," RSC Advances, vol. 3, no. 22, pp. 8286-8290, 2013.

[20] V. I. Bhoi, S. Kumar, and C. N. Murthy, "The self-assembly and aqueous solubilization of [60]fullerene with disaccharides," Carbohydrate Research, vol. 359, pp. 120-127, 2012.

[21] A. Amiri, M. Memarpoor-Yazdi, M. Shanbedi, and H. Eshghi, "Influence of different amino acid groups on the free radical scavenging capability of multi walled carbon nanotubes," Journal of Biomedical Materials Research - Part A, vol. 101, no. 8, pp. 2219-2228, 2013.

[22] W. Guoxiu, Y. Juan, P. Jinsoo et al., "Facile synthesis and characterization of graphene nanosheets," Journal of Physical Chemistry C, vol. 112, no. 22, pp. 8192-8195, 2008.

[23] S. Dutta, N. Karak, J. P. Saikia, and B. K. Konwar, "Biocompatible epoxy modified bio-based polyurethane nanocomposites: mechanical property, cytotoxicity and biodegradation," Bioresource Technology, vol. 100, no. 24, pp. 6391-6397, 2009.

[24] H. Noritomi, R. Kai, D. Iwai et al., "Increase in thermal stability of proteins adsorbed on biomass charcoal powder prepared from plant biomass wastes," Journal of Biomedical Science \& Engineering, vol. 4, no. 11, pp. 692-698, 2011.

[25] R. Gaudana, V. Khurana, A. Parenky, and A. K. Mitra, "Encapsulation of protein-polysaccharide HIP complex in polymeric nanoparticles," Journal of Drug Delivery, vol. 2011, Article ID 458128, 7 pages, 2011.

[26] N. Blanco-Pascual, F. Fernández-Martín, and M. P. Montero, "Effect of different protein extracts from Dosidicus gigas muscle co-products on edible films development," Food Hydrocolloids, vol. 33, no. 1, pp. 118-131, 2013.

[27] I. Schmidt, D. Renard, D. Rondeau, P. Richomme, Y. Popineau, and M. A.-V. Axelos, "Detailed physicochemical characterization of the $2 S$ storage protein from rape (Brassica napus L.)," Journal of Agricultural and Food Chemistry, vol. 52, no. 19, pp. 5995-6001, 2004.

[28] H. M. Kwaambwa and R. Maikokera, "A fluorescence spectroscopic study of a coagulating protein extracted from Moringa oleifera seeds," Colloids and Surfaces B: Biointerfaces, vol. 60, no. 2, pp. 213-220, 2007.

[29] F. Wu, Z. Zhou, J. Su, L. Wei, W. Yuan, and T. Jin, "Development of dextran nanoparticles for stabilizing delicate proteins," Nanoscale Research Letters, vol. 8, no. 1, article 197, 2013.

[30] J. L. Liu, Z. Luo, and S. Bashir, "A progressive approach on inactivation of bacteria using silver-titania nanoparticles," Biomaterials Science, vol. 1, pp. 194-201, 2013.

[31] J. R. Morones, J. L. Elechiguerra, A. Camacho et al., "The bactericidal effect of silver nanoparticles," Nanotechnology, vol. 16, no. 10, pp. 2346-2353, 2005.

[32] R. Singh, D. Pantarotto, D. McCarthy et al., "Binding and condensation of plasmid DNA onto functionalized carbon nanotubes: toward the construction of nanotube-based gene delivery vectors," Journal of the American Chemical Society, vol. 127, no. 12, pp. 4388-4396, 2005.

[33] M. R. Gartenberg and J. C. Wang, "Positive supercoiling of DNA greatly diminishes mRNA synthesis in yeast," Proceedings of the National Academy of Sciences of the United States of America, vol. 89, no. 23, pp. 11461-11465, 1992. 

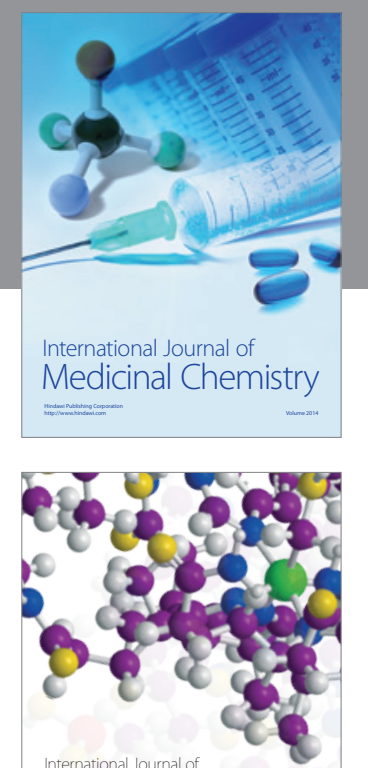

\section{Carbohydrate} Chemistry

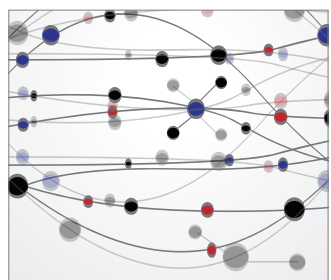

The Scientific World Journal
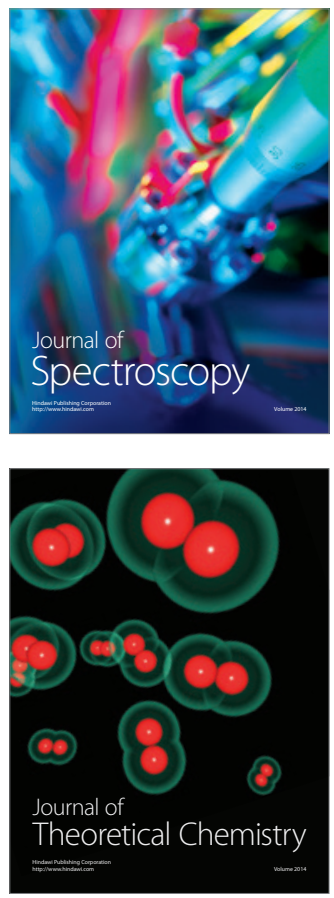
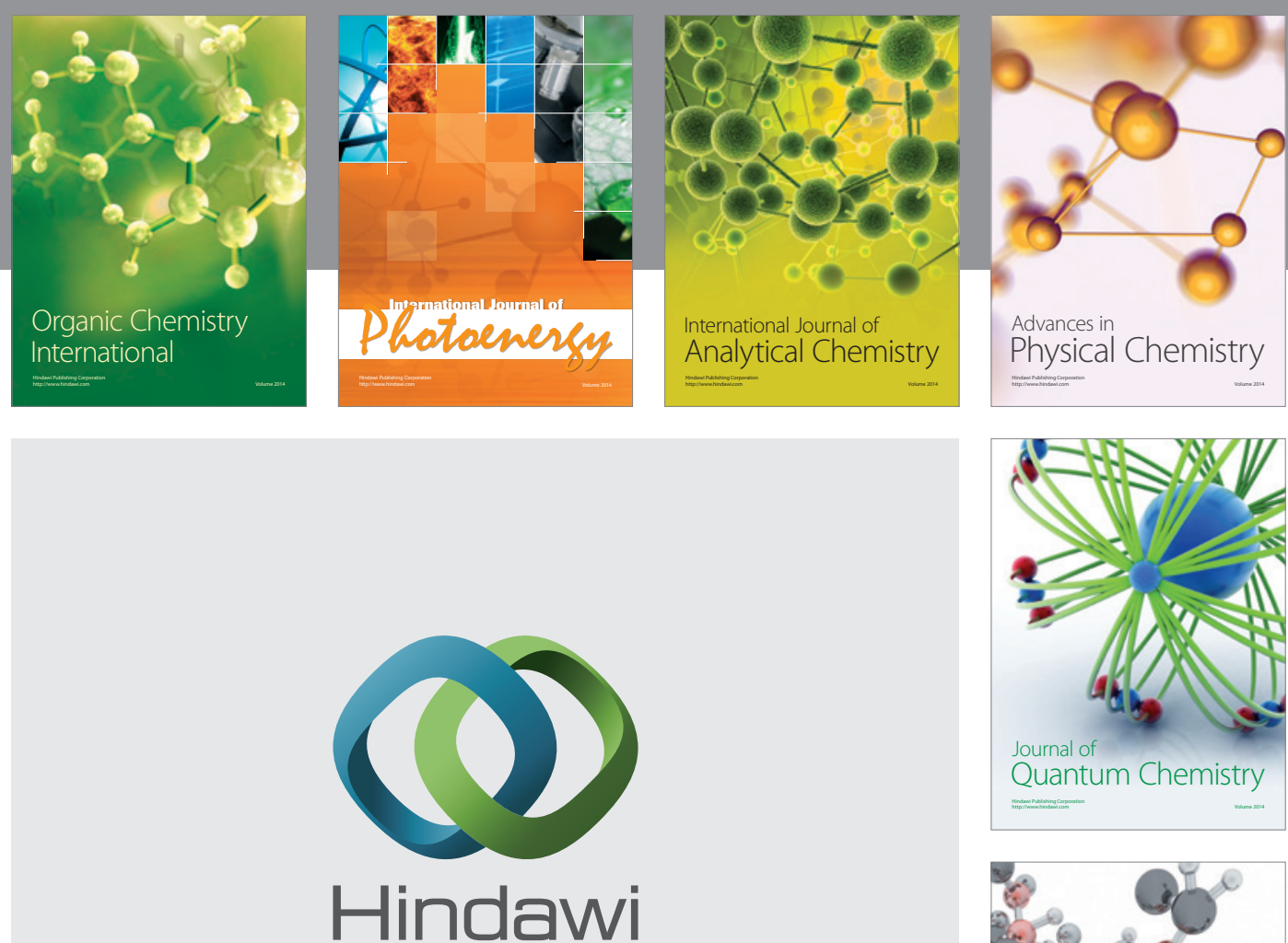

Submit your manuscripts at

http://www.hindawi.com

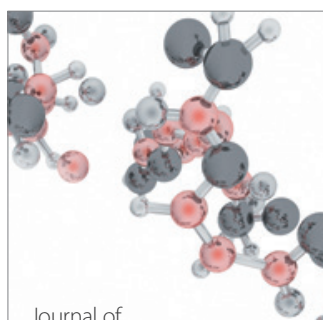

Analytical Methods

in Chemistry

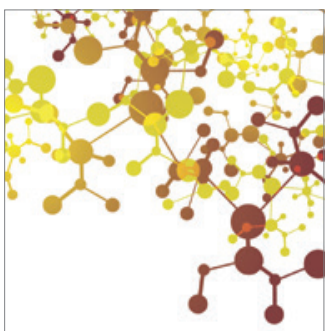

Journal of

Applied Chemistry

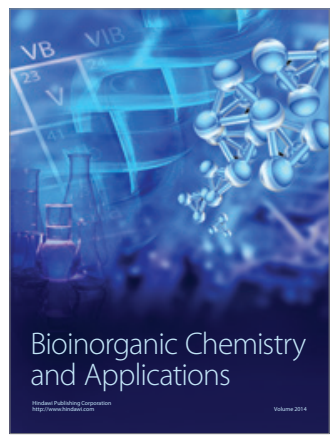

Inorganic Chemistry
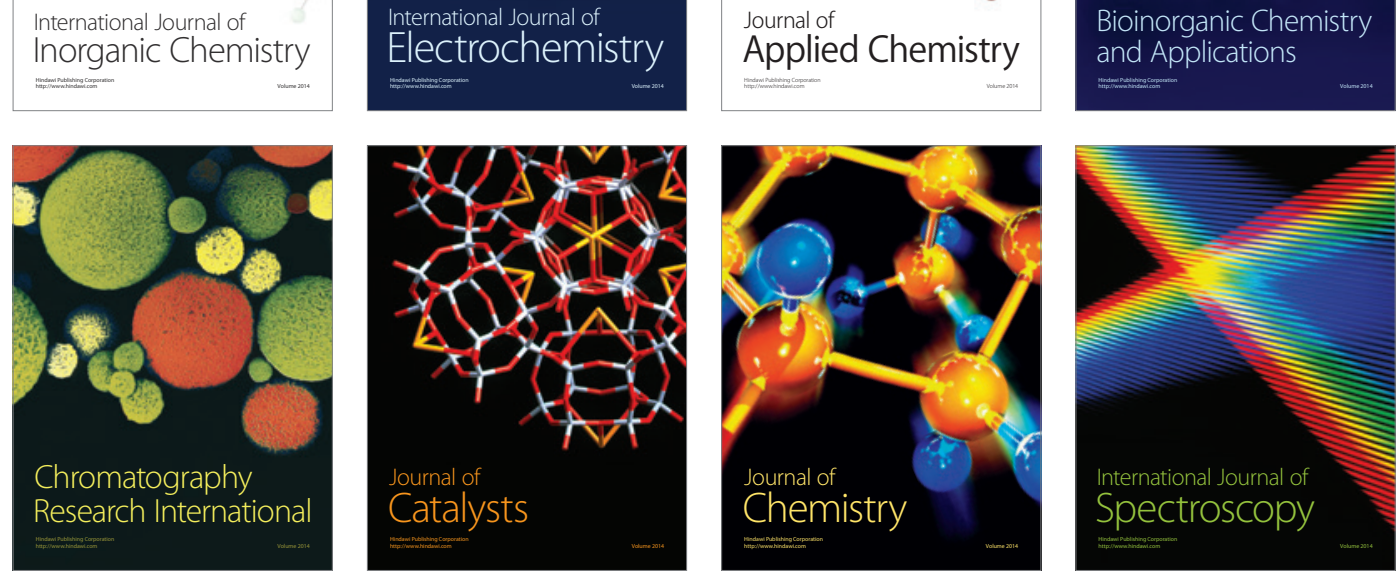